\title{
Bowing for Forgiveness in The Brothers Karamazov
}

\author{
Sara Elizabeth Whitlock ${ }^{\mathrm{a}}$
}

The Eastern Orthodox tradition of bowing heavily influences the work of Fyodor Dostoyevsky, and his final novel, The Brothers Karamazov, contains many instances of bowing at developmental moments for protagonists. By setting the novel's action during the Lenten season, Dostoyevsky allows the characters to participate vicariously in the Sunday of Forgiveness, an Orthodox service of bowing and forgiveness. When viewed in light of the book's narrative timeline and the Sunday of Forgiveness traditions, the major bows in The Brothers Karamazov can be interpreted as requests for forgiveness.

Keywords: The Brothers Karamazov; Bowing; Eastern Orthodox; Sunday of Forgiveness; Cheesefare Sunday

In 1840 William Palmer, an Anglican visitor to Russian Orthodox services, was intrigued by the orthodox practice of an "abundance of...bowing" which includes "prostrating and touching the ground with the forehead," exercises which differed sharply from Western liturgical practice (Courtney 89, 93). This Eastern Orthodox tradition of bowing heavily influences the work of Fyodor Dostoyevsky, and his final novel, The Brothers Karamazov, contains many instances of bowing at developmental moments for protagonists. By setting the novel's action during the Lenten season, Dostoyevsky allows the characters to participate vicariously in the Sunday of Forgiveness, an Orthodox service of bowing and forgiveness. When viewed in light of the book's narrative timeline and the Sunday of Forgiveness traditions, the major bows in The Brothers Karamazov can be interpreted as requests for forgiveness.

The Eastern Orthodox Sunday of Forgiveness service is inspired by the actions of bowing in the Judeo-Christian Bible. Bowing is performed by believers who "bow down toward [God's] holy temple and give thanks" in appreciation for God's saving grace and by believers "[bowing] their heads and [worshiping]" as a sign of reverence towards God (The English Standard Version Bible, Ps. 138:2; Ex. 4:31). Most pertinent to Dostoevsky's purposes, the Bible contains instances of bowing when a believer asks another believer for forgiveness. Abigail bows in this manner when she falls "before David on her face and bow[s] to the ground" asking that he "forgive the trespass of [David's] servant," her offensive husband Nabal (I Sam. $25: 23,28)$. This example links the act of bowing with a request for forgiveness in Biblical tradition, as do others ${ }^{1}$.

Although the Biblical practice of bowing as a request for forgiveness has been abandoned by most Western churches, it has been maintained in the Eastern Orthodox tradition. This type of bowing usually occurs during the last Sunday before Lent, called the Sunday of Forgiveness or Cheesefare Sunday (lent.goarch.org). In this service, "the faithful approach the priest and one another asking for mutual forgiveness" (Schmemann, actiochian.org). This action occurs during the dismissal, and "one by one, each parishioner bows or prostrates, first before the priest, and then each other, asking, "Forgive me, a sinner"' (Smith, Firstthings.com). The person addressed then "responds with a bow or prostration, asking also for forgiveness and assuring, "God forgives," and then the believers exchange the kiss of peace (Smith, Firstthings.com). The Sunday of Forgiveness links the action of bowing in Russian culture, which is influenced by Eastern Orthodox Christianity, to the request for forgiveness from another individual.

In The Brothers Karamazov, the character Zosima's most significant demonstration of bowing occurs early in the novel when he has donned the cassock for many years. In a passage that has undergone numerous interpretations, Zosima bows to Dimitri Karamazov. During the discussion intended to resolve the financial difficulties of Fyodor and his sons following Dimitri's first parricidal comment, Zosima, "kneeling in front of Dimitri Fyodorovich,...bowed down at his feet... and even touched the floor with his forehead" (Dostoyevsky 74). He then asks the group for forgiveness while "bowing on all sides to his guests" (Dostoyevsky 75). Although this passage appears to connect bowing and forgiveness, Zosima has no reason to ask for forgiveness, because he has not obviously offended Dimitri or other members of the group. Zosima later explains that he "bowed... to his great future suffering," a statement that shifts the emphasis of the bow from a request for forgiveness to a prediction of the future when considered in isolation (Dostoyevsky 285). How then to read Zosima's bow? I will argue that this mysterious action becomes the prototype for Zosima's most profound belief: that all are guility for all for everyone and everything.

Throughout the novel, bows occur in connection with forgiveness. Even the most marginal instances demonstrate a tight correlation between bowing and asking for forgiveness. Dimitri and Katya, especially, bow to each other several times. The first instance of bowing occurs after Dimitri offers to pay four thousand roubles to rescue Katerina's uncle from debt if the family will "secretly send [him Katya]" (Dostoyevsky 112). Surprisingly, Katerina accepts this immoral offer and comes to Dimitri to get the money. When he sees her sense of pride relatively intact, however, he tells her that "four thousand is too much" and that he would pay "perhaps two hundred" for time with her (Dostoyevsky 114). This statement enrages Katya, but then Dimitri gives her the money without realizing his goal and "stepping back, [bows] deeply to her, with a most respectful and heartfelt bow" (Dostoyevsky 114). Interestingly, Katya

${ }^{1} 2$ Kings 5:18, Gen 50: 15-21, Matt 18: 23-29, 2 Sam
19:18-20

a. John Brown University, Siloam Springs, AR, 72761 
then takes the money and "[falls] right at [Dimitri's] feet - with her forehead to the ground" (Dostoyevsky 114). In this scene, then, both parties bow to each other because both have committed offences which necessitate a plea for forgiveness. Dimitri bows to Katya because he desires forgiveness for his lewd request and subsequent humiliating comment that Katya is not worth the full four thousand roubles he initially promised. Katya in return bows to Dimitri for forgiveness because she intentionally goes to Dimitri knowing that she will tempt him to sin and also perhaps because she felt, throughout their interaction, that she was superior to Dimitri, a feeling she displayed "in the look on her face" (Dostoyevsky 114).

Later in their relationship, Dimitri bows to Katya again asking for forgiveness when he ends their engagement. Instead of ending his engagement in person, Dimitri asks Alyosha to "go to Katerina Ivanovna[...] and tell her: 'He says he bows to you"" (Dostoyevsky 122). Later in the text, Dimitri himself explains the significance of this bow in a letter he sends with Alyosha to Katerina saying, "farewell to you. I bow to you, to the ground, for I am a scoundrel before you. Forgive me" (Dostoyevsky 618). This bow as a request for forgiveness was necessary for the pain Dimitri inflicted upon Katya by ending their engagement and also because he "began seeing Grushenka" and "ceased to be a fiancé and an honest man" while he and Katya were engaged (Dostoyevsky 118).

Similarly, Grushenka bows to Dimitri when she temporarily ends their relationship to pursue her former Polish lover. As when Dimitri ends his relationship with Katya, Grushenka does not speak personally with Dimitri; instead, she asks Alyosha to "bow to [his] brother Mitenka for [her], and tell him not to think ill of [her], his wicked woman" (Dostoyevsky 358). This bow is a necessary request for forgiveness from Dimitri because, as Grushenka later admits, she "tormented [Mitya] from spite" by feigning insincere interest in him and enjoyed this position of relative power over him (Dostoyevsky 438).

Not only do these bows between the couples connect bowing with forgiveness, but also Zosima's bows at his conversion and his death demonstrate this connection. As a young man, Zosima has an orderly named Afanasy whom he beats in a fit of rage. Once Zosima realizes that Afanasy is "his fellow man" and that he is "guilty before everyone and for everyone," Zosima apologizes to Afanasy and asks for forgiveness (Dostoyevsky 298). Seeing, however, that the apology is "not enough," Zosima "[throws himself] at [Afanasy's] feet with his forehead to the ground" and asks Afanasy to "forgive [him]" (Dostoyevsky 298). In this situation Zosima himself shows the connection between bowing at Afanasy's feet and asking for forgiveness. Furthermore, realizing his guilt, Zosima converts to Christianity and becomes a monk, thereby not only linking bowing with forgiveness but also suggesting the influence of the Sunday of Forgiveness traditions on his choice to bow.

The final bow Zosima performs occurs at his death. As he is dying, Zosima "[lowers] himself from his armchair to the floor and [kneels], then [bows] down with his face to the ground...as if in joyful ecstasy" and "kiss[es] the earth" (Dostoyevsky 324). This does not immediately appear to be a request for forgiveness. Yet Zosima previously recalls how "[his] young brother asked forgiveness of the birds" and that "it [was] right" of Markel because "all is like an ocean, all flows and connects" (Dostoyevsky 319). In light of Markel's demonstration of asking forgiveness from nature and Zosima's observation that all of nature is connected, the bow to the earth Zosima performs before he dies is his request for forgiveness from the entire world because he views himself as "guilty before everyone" (Dostoyevsky 298). In light of the multitude of bows performed as requests for forgiveness and Zosima's belief in his guilt before the world, his bow to Dimitri and the guests can also be interpreted as a request for forgiveness. His bows to all individuals present foreshadow the bow requesting forgiveness from the entire world that he performs on his deathbed. As he will request forgiveness from the entire world, he requests forgiveness from each individual because he is "guilty before everyone" (Dostoyevsky 298). Similarly, his bow to Dimitri demonstrates that he asks forgiveness from Dimitri because he foresees Dimitri's suffering and counts himself responsible for this suffering. From his conversion to his death, Zosima emphasizes this status of perpetual and universal culpability. If one accepts his conclusion and emulates his action, then the request for forgiveness will lead to a converted life.

The acceptance of guilt before the world and subsequent bow to request forgiveness is not only critical in Zosima's life. The choice to emulate Zosima and bow to request forgiveness or reject his example profoundly affects the fate of the characters at the end of the novel. Following Zosima's death, his protégé Alyosha imitates Zosima by performing a bow for forgiveness which resembles two of Zosima's bows. After seeing a vision while beside Zosima's coffin, Alyosha is moved to convert to Christianity, "[throws] himself to the earth" and, while "kissing it, weeping, sobbing, and watering [the earth] with his tears," he says that he "[wants] to forgive everyone...for everything, and to ask forgiveness... for all and for everything" (Dostoyevsky 362). His motivation for asking forgiveness from the world, like that of his mentor Zosima, is the belief that he is guilty before the entire world and, therefore, must ask everything for forgiveness. This bow, then, is similar to Zosima's first bow in that it occurs during Alyosha's conversion but also includes the element of Zosima's final bow in which he requests forgiveness for sins detrimental to the whole world. From this point on in the novel, Alyosha lives as a new man.

On the other hand, Ivan refuses to follow Zosima's example. Smerdyakov states that Ivan loves "living in peaceful prosperity, without bowing to anyone" when confronting Ivan with his role in the death of Fyodor (Dostoyevsky 632). In the moment, Ivan decides to admit his guilt at Dimitri's trial and ask for forgiveness, but ultimately Smerdyakov's statement is accurate, and Ivan never confesses his role in Fyodor's death. In contrast to the other characters, Ivan alone will not bow even to request forgiveness for his own sins. Thus, by the end of the novel, Alyosha, Dimitri, Katya, and Grushenka practice forgiveness and experience a level of hope for the future, but the consequences of refusing to ask for forgiveness quickly overtake Ivan. He struggles with his guilt in a vision of the devil and later succumbs to a "fever" and falls "unconscious" as a physical manifestation of his guilt (Dostoyevsky 757).

Members of modern Western culture do not usually spend time on bended knee or with faces pressed to the ground. The act of bowing entails physically placing oneself below another, indicating submission, reverence, and humility; however, most members of Western society, whether due to pride, as in the case of Ivan, or just a paradigmatic assumption of 
individualism, do not voluntarily place themselves in a position of subservience. Furthermore, when viewed through the lens of Eastern Orthodox traditions and the example of the characters in The Brothers Karamazov where bowing also symbolizes a request for forgiveness, this action becomes even more uncomfortable. Hopefully, unlike Ivan, members of Western culture find a way to request forgiveness, via bowing or otherwise, less they too suffer the consequences of their guilt.

\section{References:}

Courtney, Julia. "LISTENING TO VOICES FROM THE EAST: NINETEENTH CENTURY ANGLICANS AND THE RUSSIAN ORTHODOX CHURCH." Текст. Книга. Книгоиздание (2014): 89-105. Web. 2 Мау 2015.
Dostoevsky, Fyodor. The Brothers Karamazov. Trans. Richard Pevear and Larissa Volokhonsky. New York: Farrar, Straus and Giroux, 2002. Print.

Schmemann, Alexander. "Forgiveness (Cheese-Fare Sunday)." actiochian.org. Antiochian Orthodox Christian Archdiocese, n.d. Web. 14 April 2015.

Smith, Wesley J. "'Forgiveness Sunday' Opens The Door To Orthodox Lent." firstthings.com. 7 March 2014. Web. 14 April 2015.

"The Fourth Sunday Of The Triodion Period: Sunday of Forgiveness (Cheesefare Sunday)." lent.goarch.org. The Department of Internet Ministries of the Greek Orthodox Archdiocese of America, n.d. Web. 14 April 2015

The Holy Bible, English Standard Version. Wheaton: Crossway Bibles, 2001. Print. 